\title{
Breast Cancer Illness and Spiritual Healing
}

\section{By Szariannie Binti Sulaiman \& Noor Azlan Bin Mohd Noor}

International Islamic University Malaysia (IIUM)

Abstract- Spirituality, religion and family play pivotal roles in addressing issues related to one's illness experiences. The illness experiences were perceived as a moral-religious experience rather than a mere suffering due to bodily dysfunctions. Thus, this qualitative study aimed at exploring the concept of spirituality in the lives of young Malay breast cancer patients. An ethnographic fieldwork was carried out among 13 young Malay breast cancer patients in Klang Valley and several selected areas of Selangor, Malaysia. A purposive snowballing technique was employed to select the informants for the study. A series of in-depth interviews, phone and online interviews guided by semi-structured interview schedule and participant observation were carried out among the informants. It is evident from the study that the manifestation of spiritual experiences in relation to their breast cancer is attributed to the spiritual meaning of breast cancer illness, roles of family in providing spiritual support and medical pluralisation. The informants attributed their breast cancer illness as qada' and qadar of Allah. They accented it as ujian (test) or balasan (divine punishment) for a good cause from Allah S.W.T. On this account, spiritual healing was sought as complementary to hospital treatment in searching a cure for breast cancer.

Keywords: breast cancer illness, medical pluralisation, religious belief, spirituality, spiritual support.

GJHSS-A Classification: FOR Code: 190499, 370199

Strictly as per the compliance and regulations of:

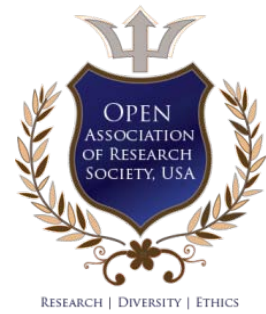

(C) 2021. Szariannie Binti Sulaiman \& Noor Azlan Bin Mohd Noor. This research/review article is distributed under the terms of the Attribution-NonCommercial-NoDerivatives 4.0 International (CC BY-NC-ND 4.0). You must give appropriate credit to authors and reference this article if parts of the article are reproduced in any manner. Applicable licensing terms are at https://creative commons.org/licenses/by-nc-nd/4.0/. 


\title{
Breast Cancer IIIness and Spiritual Healing
}

\author{
Szariannie Binti Sulaiman ${ }^{\alpha} \&$ Noor Azlan Bin Mohd Noor ${ }^{\sigma}$
}

\begin{abstract}
Spirituality, religion and family play pivotal roles in addressing issues related to one's illness experiences. The illness experiences were perceived as a moral-religious experience rather than a mere suffering due to bodily dysfunctions. Thus, this qualitative study aimed at exploring the concept of spirituality in the lives of young Malay breast cancer patients. An ethnographic fieldwork was carried out among 13 young Malay breast cancer patients in Klang Valley and several selected areas of Selangor, Malaysia. A purposive snowballing technique was employed to select the informants for the study. A series of in-depth interviews, phone and online interviews guided by semi-structured interview schedule and participant observation were carried out among the informants. It is evident from the study that the manifestation of spiritual experiences in relation to their breast cancer is attributed to the spiritual meaning of breast cancer illness, roles of family in providing spiritual support and medical pluralisation. The informants attributed their breast cancer illness as qada' and qadar of Allah. They accented it as ujian (test) or balasan (divine punishment) for a good cause from Allah S.W.T. On this account, spiritual healing was sought as complementary to hospital treatment in searching a cure for breast cancer. It can be suggested that the role of religious belief is significant in determining breast cancer patient's pluralistic attitude towards treatment option. It was also observed that spiritual support from family was significant during the illness episode. The most significant and important sources of family support were parents and husband.
\end{abstract}

Keywords: breast cancer illness, medical pluralisation, religious belief, spirituality, spiritual support.

\section{InTRODUCTION}

S pirituality, religion, and family play pivotal roles in addressing issues relating to breast cancer prognosis and treatment. The diagnosis of breast cancer proved to be distressing and to some, considered as unforgiven episode in one's lifecycle. It is a life-changing diagnosis. The sufferings and pain as breast cancer patients are unbearable, particularly to the family and social relationships within the society at large. The prognosis to the diagnosis of breast cancer is uncertainty. This includes prolong treatment and palliative health care management, emotional distress, anxiety, acute fear, depression and trauma, to list down a few. The sufferings due to cancer could be either a disease or illness-related symptom of experience.

Author a: Assistant Professor at Department of Sociology and Anthropology, Kulliyyah of Islamic Revealed Knowledge and Human Sciences, International Islamic University Malaysia (IIUM), Jalan Gombak, 53100, Kuala Lumpur, Malaysia.e-mail: sza@iium.edu.my

Author 0: Associate Professor at Department of Sociology and Anthropology, Kulliyyah of Islamic Revealed Knowledge and Human Sciences, International Islamic University Malaysia (IIUM), Jalan Gombak, 53100, Kuala Lumpur, Malaysia.

e-mail: noorazlanmn@iium.edu.my
According to Kleinman (1997), issues surrounding cancer-related sufferings were multitudinous, complex and not delimited to medical phenomena and justified merely within the biomedical framework. The suffering itself was a moral-religious experience that emphasized paradoxically, not how to avoid suffering, but how to suffer (Kleinman, 1997: 331).

\section{Literature ReVieW}

Suffering, to Kleinman (1997: 320-330) is social for (1) it is often a transpersonal engagement with pain and misery in social relationships, as in a family tragedy; (2) it is a societal construction that acts as a cultural model, a moral guide of and for experience, and (3) it is also a professional discourse that organizes forms of suffering as bureaucratic categories and objects of technical intervention, such as the professional conversion of illness experience into disease pathophysiology. It was evident from several cancerrelated cases descriptions that the patients' illness experiences were a moral-religious experience rather than in medical terms alone. The sufferings were not just being social, but relatively a religious question that involved inquiries of how people perceived and renegotiated meanings of any breakdown or disruptive human conditions observed in diverse contexts. The suffering body then, became the meeting place of the human and the divine. The healing became the material manifestation of one's belief towards religion of which in this case, i.e., Christianity. Christianity was involved in a transformation of subjectivity. This new subjective self as sufferer took social suffering as processes that connect the moral to the medical, the political to the emotional, and the religious to the physiological.

Devi and Fong (2019) discusses spiritual experiences among breast cancer women in a multiethnic and multi-religious society of Singapore. The discussion offers a great insight towards the concept of spirituality. The manifestation of spiritual experiences in relation to their breast cancer diagnosis vary across the culture and religion. The study shows that religion, family and culture were found to be significant in shaping their personal and community values. Most of the cases deliberated had common spiritual experiences namely, getting closer to God, became strong believer to what they believed about religion, and spent more time for spiritual activities such as frequently visited to places of worship and offered prayers which gave them inner strength to move on and placing high hope for a cure. There were three (3) major themes discovered in relation 
to their spiritual experiences, namely transcendental experience, new meaning and purpose in life, and changing perspective about life. For Muslim patients, they accepted the cancer diagnosis as God's will and was a divine test. As for Indian women, Hinduism taught them to subscribe to the belief of Karma, the law of causality. They believed that they were destined to have cancer as a consequence of the bad deeds or sinned committed in their earlier life. In other words, spirituality assisted them to view their life from a new perspective including learning to let go, understanding of self and appreciating meaning of relationships with others.

For instance, Farizah et al. (2011) in their study in Malaysia found that among Muslim women with advanced stage of breast cancer, illness is perceived as a life-awakening experience. As for these women, being diagnosed with breast cancer has made them appreciate their lives more than before. It had brought them closer to Allah by establishing a deeper and profound relationship with Him. Additionally, having been diagnosed with breast cancer have made them realise that everything happens for a reason, be it good or bad, under the dominion of Allah. As Muslim, they strongly believed that having breast cancer is a sign of Allah's love and grace for His servants rather than a punishment. Consequently, they find themselves to be able to cope with the adversity of life after breast cancer diagnosis. They have a positive acceptance that breast cancer is a gift from Allah for His chosen servants, and thus, perceive life and death in a prospective manner. For them, life is full of trials and death is the return of one's soul to the Creator.

As for Movafagh et al., (2017), the spirituality concept was further examined in the context of health care among cancer patients including breast cancer patients from diverse and heterogeneous populations around the globe. Religion and spiritual therapy were adopted by cancer patients as their coping strategy in dealing with the cancer prognosis and treatment. Their spiritual beliefs might have empowered them to endure the pain throughout the therapeutic process. Majority of the cancer patients believed that their spiritual wellbeing, health care prognosis, and fate lie in the hands of God and beyond control of any physicians. Muslim patients in particular, considered illness suffered as rewarding, God's will and not divine punishment. This was evidently observed in several Muslim countries such as Iran, Saudi Arabia and Malaysia. In essence, it was a well-woven perspective and integrated package of spiritual elements observed among cancer patients including contemplation, prayer, gratitude, trust, and repentance as such, in promoting their health status. The study had shown that there is a high demand of spiritual palliative care i.e., spiritual care in Islamic context, particularly among Muslim cancer patients in promoting health status. In Malaysia for instance, several Malay Muslim female patients refused or discontinued treatment and opted for spirituality as a means of fighting their breast cancer. In relation to this, it was evident and imperative for clinical oncologists to be aware of the prevalence of the use of spirituality as Complementary/Alternative Medicine (CAM) in oncology which was frequently sought for a cure by cancer patients (Movafagh et al. 2017: 85-86).

Leao et al., (2021) discuss the role of spirituality in health care and social well-being of women breast cancer patients in Brazil. Spirituality deemed to be an important resource for women with breast cancer especially in matters relating to cancer diagnosis and treatment decisions. Five (5) themes were identified in this study as foundation that supports the complex process of illness caused by breast cancer, namely, (1) meaning of spirituality leading to source of spiritual strength; (2) well-being in the relationship with God; (3) well-being in religious fellowship; (4) values and purpose of life-meaning in life; and (5) spirituality as a foundation to continue realising their capacity to positively reformulate their life purpose and maintain equilibrium with courage and confidence (Leao et al. 2021: 4-7). In essence, the spiritual dimension of health care focuses on the integration of the physical, emotional, and spiritual well-being. This study had also emphasised the importance of family support to breast cancer patients especially in creating an environment of empathy in facing trauma and uncertainty. Family is considered as a source of fortitude for the patients.

Miller (2021) discusses spirituality and its relationships with pain symptom management among women suffering from breast cancer. They cited spirituality as an important resource for facing their disease experience, including their symptoms. There was evidence in the study that spirituality increases the use of self-management interventions focused on relieving pain, thus indirectly improving their symptoms. Several themes were identified in understanding spirituality and pain experience. These included (1) spirituality provides positive cognitive framing to help women face pain; (2) spirituality elicited supportive emotions such as peace and tranquillity despite pain; (3) spiritual practices serve as pain self-management tools; and (4) connection with others and service activities (aspects of spirituality) help women cope with pain (Miller, 2021: 3). According to Miller, spirituality served as an asset and a beneficial resource for breast cancer patients to reduce fear of unknown, fear of death, getting connected and closer to God through spiritual practices such as meditation and prayers, renegotiating expectations and acceptance towards pain management process. In other words, it is pertinent to understand social pain beyond medicine, its generation mechanism and maintenance leading to physical pain (Singh, 2017: 132-133).

In another study among Ojibway cancer patients in Canada, Barkwell (2005) suggests that the 
symptom of cancer pain is multidimensional and contagious for it could not only disrupt the patients' physical, psychological and spiritual aspects of life but could also affect other people's lives as well. Among the Ojibway people, cancer is a topic that everyone would avoid talking about and is considered taboo in their community. They believe that talking or thinking about it would invite the illness to be real or cause a person to be vulnerable to the illness. For this reason, they keep the symptoms of pain suffered from this illness within themselves. Only after the pain becomes severe and they could no longer bear it, they would seek help from traditional healers in the community. They perceive the symptoms of pain from various dimensions of their lives. These include describing the pain as physical sensation and having many levels of intensity such as bad pain, burning pain, heavy pain and sharp pain. Aside from that, the suffering from the symptoms has forced them to acknowledge the reality of having cancer and causing them to develop fear and become helpless. Instead of relying on 'pain killers' or medicine to endure the pain, they perform prayers and rituals for they believed these could bring themselves closer to God and address the spiritual anguish of having to live with cancer. By doing so, they could gain the spiritual strength to fight back the fear and the suffering of pain stimulated by the cancer diagnosis. It was also observed that the suffering of pain could be felt by others particularly caregivers, relatives and traditional healers for they are directly involved in providing care and dealing with patients in pain.

In relation to this, Kleinman (2019) highlighted the importance of the human soul i.e., the innermost existential centre to human being, as an important element for treatment management process. He observed that the contemporary caring in health-care system was "soulless" i.e., failed to implicate the soul that required much care and not medical management. $\mathrm{He}$ admitted the limits of drugs and psychotherapy in treating chronic diseases and other human health crises management. The fundamental plea for chronic patients would be to understand why bad things happen to them and to ask for help, divine and secular. What really matters would be to implicate the soul of which such moral and religious experiences are better left neither pathologised nor medicalised. Such approach is imperative for quality health care management of chronic patients, family members and clinicians (Kleinman, 2019: 631).

Aside from this, Hassan Mahmud et al., (2019) in their study in Bangladesh had highlighted that the crucial context of understanding cancer is its social implications particularly on treatments \& therapy seeking process. The therapy seeking process adopted by cancer patients for instance, involved both perceived and social supports. For social support, the adjustment predictors included prognosis, chronicity of illness, pain, culture and social environment influence, and patient's socio-psychological resources. Those adjustment predictors were crucial for patients in mitigating symptoms of distress due to cancer. They adopted different coping mechanisms based on their cultural contexts in describing pain. The pain suffered could be mental, physical, physiological and to some extent, psychological and economic deprivation due to poverty. Most patients in Bangladesh, were poor and lived below poverty line. They took economic suffering into their consideration in care-seeking decision for a cure. Thus, their medical pluralistic attitude in relation to careseeking decisions and social relations were very much influenced by their socio-cultural and economic factors. They opted for affordable alternative treatments such as homeopathy, Ayurveda, and other folk medicine to mitigate their cancer-related symptoms of distress. According to Horbst et al., (2017: 8-14) medical pluralistic attitude or medical pluralisation among chronic patients in care-seeking decisions is common. The medical pluralism described patient's options for diverse treatment realities in addition to biomedical healing process. Such options for alternative treatments were within the variability and contexts specificity of healing in dealing with chronic patients (Horbst et al., 2017: 9-13).

Norhasmili et al. (2015) state that the use of traditional and complementary medicine (TCM), particularly Islamic healing techniques which have become increasingly popular among Muslim cancer patients in Malaysia. The study indicates that the medical pluralistic attitude in seeking treatment among these cancer patients could be due to 'seeking for cure' for chronic illness like breast cancer or any cancer related illness or disease. It was observed that the roles played by immediate family, religious and cultural beliefs were significant among these cancer patients seeking for cure. The study shows that these cancer patients relied heavily on the opinions and advice given by their husband and parents with regards to seeking for cure. They believed that the healing would be effective when accompanied by the blessing and full support of their husband and parents. They strongly believed only Allah will cure their cancer and it caused them to be closer to Him in searching for a cure. This could be done by practising the Islamic mode of healing like reciting and practising Al-Qur'an in daily life.

\section{Methodology}

\section{a) Study Area and Population}

A fieldwork for ethnographic details was conducted in Klang Valley and the state of Selangor Malaysia. Several areas within the state of Selangor had been selected for the fieldwork to explore further the concept of spirituality among young Malay women suffering from breast cancer symptoms. The justification 
for the research sites selection was decided based on the highest number of breast cancer cases reported.

\section{b) Sampling}

A purposive snowball sample of 13 young Malay breast cancer patients was drawn from the National Cancer Council (MAKNA), the 'gate keeper' that provides access to potential informants for this study. The informants were selected based on the following selection criteria; 1) must be women of Malay ethnicity as the study focuses on Malay women; 2) must be of young age defined in the study which is within the age range of 25 to 49 years old and 3) must be among breast cancer patients or survivors.

\section{c) Data Collection Procedure and Analysis}

This fieldwork emphasised qualitative approach as far as data collection procedure was concerned. For this purpose, in-depth interview using interviewschedule, participant-observation technique, field diary, and field notes as such, were utilised. The main objective of the fieldwork was to secure ethnographic details of issues faced by breast cancer patients in addressing their breast cancer symptoms. Several potential informants were identified and contacted through phone calls prior to any commencement of interview session. This was meant to seek their consent prior to making appointments for interview and their participation in the study. All informants participated were given assurance for the confidentiality of data collected.

The in-depth interview session with informants was conducted in several ways, namely, face-to-face, over the phone, or online interview. The interview sessions went on for about 45 minutes to one hour and thirty minutes per session using interview-schedule. Questions formulated for the interview sessions with the informants included their demographic details, health behaviour, illness experience, concept of spirituality from patients' perspectives, medical compliance, and reasons for CAM (Complementary/Alternative Medicine). Most of the interview-sessions were held face-to-face at various settings such as at informants' house, hospital area, oncology ward, cafeteria and hotel lobby. The face-to-face interview sessions conducted gave greater insights for the researcher to understand issues surrounding cancer, particularly breast cancer symptoms and treatment. Occasionally, the interview sessions would be conducted through phone calls or other social media platforms due to unforeseen circumstances such as time constraints and health factors. In the meantime, the researcher also employed participant-observation and field diary approaches in recording events observed in the fieldwork. On many occasions, the researcher had the opportunity to be in the hospital settings for several events. These included, accompanying informants for medical appointments, observing on records about medical compliance in relation to treatments and medications, issues surrounding hospitalisation, doctor-patient relationships, and to some extent, attending their funerals too.

As for data analysis, the researcher employed thematic content analysis technique. Fieldwork data together with information recorded in the field diary were analysed accordingly by the researcher. Coding procedures were applied based on the themes formulated and generated from the field data. Such coding procedures and thematic analysis had helped the researcher to explore and draw coherent findings in discussing issues relating to cancer, breast cancer illness and spiritual healing in particular.

\section{Results and Discussion}

\section{a) Informants Demographics Profiles}

Thirteen (13) young Malay women suffering from breast cancer between the ages of 29 to 48 years old were selected for the study. They were of Malay ethnic origin who professed Islam as their religion, subscribed to the Malay adat (Malay customs), and Bahasa Melayu (Malay language) as medium of communication. Table 1 below represents the informants' demographic and health profiles.

Table 1: Informants' demographic and health profile

\section{No. Age Marital Status No. of children Educational level BC Staging}

$\begin{array}{cccccc}1 & 36 & \text { Married } & 4 & \text { Tertiary } & \text { II, IV } \\ 2 & 29 & \text { Single } & 0 & \text { Tertiary } & \text { ॥ } \\ 3 & 36 & \text { Married } & 1 & \text { Tertiary } & \text { I, II } \\ 4 & 35 & \text { Married } & 1 & \text { Tertiary } & \text { ॥ } \\ 5 & 35 & \text { Married } & 3 & \text { Tertiary } & \text { ॥ } \\ 6 & 41 & \text { Divorced } & 5 & \text { Secondary } & \text { IV }\end{array}$




$\begin{array}{cccccc}7 & 41 & \text { Married } & 3 & \text { Tertiary } & \text { ॥ } \\ 8 & 36 & \text { Married } & 3 & \text { Tertiary } & \text { ॥ } \\ 9 & 36 & \text { Married } & 3 & \text { Tertiary } & \text { ॥, IV } \\ 10 & 45 & \text { Married } & 5 & \text { Secondary } & \| \\ 11 & 42 & \text { Single } & 0 & \text { Secondary } & \text { ॥ } \\ 12 & 48 & \text { Married } & 2 & \text { Secondary } & \text { ॥ } \\ 13 & 33 & \text { Married } & 4 & \text { Tertiary } & \text { ॥ }\end{array}$

Table 1 above shows that majority of the informants interviewed were in Stage II of breast cancer symptoms. They highlighted several issues relating to their breast cancer disease or illness symptoms. Cancer including breast cancer is categorised as chronic disease and the issues faced are multitudinous and complex. In most cases, the deliberation on health behaviour and illness experiences of breast cancer patients require long-life healthcare management. The healthcare management involving treatment and medications could be varied among the patients. They believe that the diagnosis of breast cancer symptom is a crisis and life-threatening event. Thus, relying on biomedical procedure of treatments in reducing cancerrelated pain symptoms is not solely the healing option. In most cases, they succumb to medical pluralisation approach as far as healthcare management and treatment are concerned. This includes spiritual healing as one of the options sought for in alleviating their pain and distressing symptoms due to cancer. The discussion that follows below will describe several themes that can be associated with spiritual healing.

\section{b) Theme 1: The Spiritual Meaning of Breast Cancer Illness}

Informants strongly believed that one's health status is very much related to the will of Allah. On this account, several informants attributed their breast cancer illness as qada' and qadar (predestination) of Allah. They accented it as ujian (test) or balasan (divine punishment) for a good cause from Allah S.W.T. The ujian or balasan by Allah is not presumed as divine punishment due to their wrongdoings committed in the past. Instead, many informants believed that the ujian or balasan is rewarding based on the fact that with Allah's mercy they would be forgiven and could enjoy the rewards or benefits in the Hereafter. They need to accept the ujian or balasan as qada' and qadar of Allah and at the same time, bring them to stay close to Allah. The informants strongly believed that every Muslim will be tested to gauge one's iman (faith) towards Allah. This test could be in various forms such as wealthy life, good health and illness. In other words, one's iman is measured through His ujian or balasan. Thus, one has to have bersangka baik (in good faith) towards Allah. In relation to this, one of my informants, lla aged 41 narrated to me as follows:

She had breast cancer symptoms at the age of 40 . It was the greatest test in her life. At times she thought it could be a 'balasan' for her wrongdoings in the past. However, she needed to 'bersangka baik' in Allah and strongly believed in His 'qada' and qadar'. For her, everything that happened had a reason, and she became closer to Allah as a result. She always thought that every one of us has our own test in life. If she believed her test was great, others might have greater test than her.

In other instances, several informants associated their breast cancer as a form of kafarah (retribution). As Muslims, they strongly believed that one has to be held accountable before Allah in the Hereafter for whatever deeds committed in this world. The principle is any form of righteousness will be rewarded and wrongdoings will be held accountable and punished. For this, kafarah is not perceived as a form of divine punishment. Instead, it is a rewarding sign of kasih sayang Allah (Allah's mercy and grace) to His servants. Raja, one of my informants aged 42 , told to me:

She accepted her breast cancer symptoms as 'kafarah' from Allah. She remembered 'ustazah' (female religious teacher) once told her that Allah would test those whom He loved most. She believed everything given by Allah was at His mercy, and for that Allah had given her a test of breast cancer. She believed by having the 'kafarah', some of her wrongdoings have been repaid and would reduce her punishment in the Hereafter.

It is observed that Muslim breast cancer patients in this study perceived their illness as an awakening experience due to Allah's mercy. Through kafarah, one is forgiven and informants believed that the kafarah would reduce divine punishments in the Hereafter. 
Aside from kafarah, several informants described the development of breast cancer illness as Allah's will. They believed Allah is the one who makes them ill and $\mathrm{He}$ is the one who will cure them. In any given situation, either good or bad including illness, one needs to have strong faith in Allah. The question of iman and taqwa (fear Allah) will always be asked to every individual Muslim. According to Teh, as a Muslim she believed having to live with breast cancer is within Allah's will to test her level of Iman. Teh described to me as follows:

Initially she felt devastated and was beyond words to describe her feelings when the doctor told her that she had breast cancer. It was a difficult moment and took her nearly a month to accept and move forward with her life. Hashim, her beloved husband was very supportive and always be by her side when she needed him. She believed that Allah would cure her breast cancer for He was the one who made her ill. Since then, she became closer to Allah and her family. She appreciated every single second of her life particularly by performing more religious obligations towards Allah. She described her relationship with her husband became stronger and they could understand each other better in facing Allah's will of ill health.

Teh further described her gratefulness towards Allah in her health diary as follows:

Today is her $9^{\text {th }}$ anniversary. Thank you Allah for everything. She described her $9^{\text {th }}$ wedding anniversary celebration as one of Allah's mercy and grace bestowed to her after being tested with breast cancer. She never imagined to be where she is today after being diagnosed with breast cancer at a young age and had to have her right breast removed.

c) Theme 2: The Roles of Family and Spiritual Support

It is evident from the study that family is the main provider of spiritual support during the healthcare management and treatment processes. One of the informants, a 41 years old cancer patient, narrated that the roles played by her parents were important in determining her compliance with the treatment option. After completing her chemotherapy treatment, she was supposed to undergo a surgery to remove the lump from her breast. However, she requested from the doctor to postpone the surgery until her parents returned from performing Hajj (pilgrimage). At first, the doctor was quite reluctant to delay the surgery for it would bring more harm than good to her health. According to the doctor, there would be a high possibility that the cancer cells would become more aggressive. Despite the fact, she insisted on her decision. At last, the doctor agreed to postpone the surgery with condition and rescheduled it until her parents returned from performing Hajj. In on one of the interviews she said:

She wanted to wait for her parents to return from Hajj mainly because she needed the 'du'a' (prayers) and their presence as 'penguat semangat' (to boost one's spirit) for her to keep fighting. She described if anything bad were to happen to her during the surgery, she knew her parents were there with her.

Similarly, according to another informant Shah aged 36 , narrated that throughout her journey battling against breast cancer, she received invaluable encouragement from her husband. Her husband always stood by her side and supported her in all decisions she made for her treatment plans. Her husband strongly encouraged her to proceed with a breast removal surgery soon as recommended by the doctor. She said:

Her husband was amazing. He encouraged her to decide on what would be the best for her because she would be the one to bear all the consequences from the decision made. As a husband, he had nothing to disagree, instead would give his full support as much as he could. In the meantime, he encouraged her to perform 'solat Istikharah' (prayers) to seek guidance from Allah on what she had decided.

After being enlightened by her husband that the surgery was one of her ikhtiar (efforts) to fight against her cancer, she had become bersemangat (motivated) to undergo the treatment and had tremendously helped her to overcome the fear she had about the treatment. The role played by her husband in providing moral and emotional supports was significant. Shah's strong semangat or determination and perseverance to move on with her life after breast cancer and being cured from the disease had been associated with the amazing support provided by her husband.

The above cases highlighted that support from family was significant during the illness episode. The most significant and important sources of family support were parents and husband. This could be due to the Malay good values of obeying parents and husband in searching for a cure for their illness.

\section{d) Theme 3: Medical Pluralisation}

As in the case of seeking for a treatment, several informants sought for multi-combination of treatments in seeking a cure for their breast cancer symptoms. They sought hospital treatments, traditional medicine, reflexology and spiritual healings to treat the symptoms suffered. Another informant, Pah a 33 years old cancer patient mentioned that aside from seeking help from health practitioners, she also employed several self-medication to improve her well-being, such as performing solat malam (night prayer) like solat Tahajjud (prayers) in particular and reciting Al-Qur'an. Her strong believed that Al-Qur'an has curing potency for breast cancer had influenced her to adopt spiritual healing technique. This is elucidated in the text below:

After being diagnosed with breast cancer, it had made her realised of many things in life, especially her relationship with Allah. She started to perform 'solat Tahajjud' almost every night and later found her inner strength to face whatever Allah had ordained to her. This had made her become closer to Allah and made her relationship with Him become stronger. For her, cancer was a blessing in disguise and strongly believed that 'solat Tahajjud' is a cure for all illnesses. She also made it a routine to recite Al-Qur'an every day after 
'solat' for she believed it could help her to stay calm in dealing with many challenges having to live with breast cancer. Additionally, she consumed 'Sunnah food' for its medicinal benefits like improved blood circulation, provided energy and boosted immune system. Among the 'Sunnah food' she had consumed included honey, dates, 'habbatus sauda' (black seeds) and olive oil.

As for reciting Al-Qur'an, Pah narrated that previously she only recited Al-Qur'an on an occasional basis like reciting surah Yassin on Friday night. However, after her breast cancer diagnosis, she made it a routine to recite Al-Qur'an on a daily basis. She was told by one of her friends who is a breast cancer survivor that there are eight surahs (Quranic chapters) in Al-Qur'an that can be recited to destroy cancer cells in the body. This includes surah Al-Maidah (ayat 82-91), surah Al-Araf (ayat 70-81), surah Ar-Ra'd (ayat 16-28), surah AlAnbiyaa' (ayat 38-50), surah As-Syu'ara (ayat 185-227), surah Az-Zummar (ayat 42-52), surah Ghafir (ayat 67-77) and Surah Az-Zukhruf (ayat 52-70). Indeed, many Muslim cancer patients in one of the online support groups that she joined also encouraged other cancer patients like her to recite the surahs as an ikhtiar to seek a cure for their illness.

The foregoing cases highlighted that informants' strong belief in spiritual healing as another curative mechanism for breast cancer could have been influenced by their strong religious belief. Spiritual healing was sought as complementary to hospital treatment in searching for a cure for breast cancer. It can be suggested that the role of religious belief is significant in determining breast cancer patient's pluralistic attitude towards treatment option.

Islam encourages individuals to pray and seek His forgiveness and protection in ensuring good health. Thus, one's health and illness is associated with Allah's qada' and qadar. Believing in qada' and qadar to many is intimately related to one's life in this world, either for a good cause or a bad one within the guidance of Allah. A person could only change his or her qada' and qadar through du'a (prayers). The du'a could address one's qada' and qadar in all daily life matters. This includes matters pertaining to income, marriage, rezeki (sustenance), long life, health and illness. The other factor of equal importance is informants' religious values. It was observed that several informants had primarily focused on one treatment at a time to obey their parents and husband. The main reason for this is to seek for blessings or barakah and most importantly, their prayer or du'a. They believed that selecting which treatment alone is insufficient without their blessings especially for parents and husbands of married women. For many informants, Islam has taught them to believe that every event including illness comes from Allah. In order to seek pleasure and barakah from Allah, one has to follow His teachings. One of the teachings include obeying or seeking blessings from parents for unmarried women and husbands for married women. They believed following the advice and decisions made by parents or husbands could eventually assist breast cancer patients to search for a cure. Furthermore, it is one of the important values or tenets taught in Islam.

Family support is another important dimension in influencing one's decision prior to utilising any form of treatment. There are various reasons for this. Several informants strongly believed that having family members especially parents and spouses, could actually assist them in dealing with chronic pain like breast cancer. They could turn their sufferings to their loved ones in alleviating the pain. In most occasions, they would seek advice on how to go about in treating the illness suffered.

Malay breast cancer patients exhibited pluralistic attitude towards seeking a cure for their illness. In relation to that, they sought multiple combinations of treatment to treat the symptoms suffered. They strongly believed seeking a single treatment would be insufficient to treat chronic illnesses like breast cancer. It was observed that several informants had primarily focused on one treatment at a time to obey their parents and husband. The main reason for this is to seek for blessings or barakah and most importantly, their prayer or du'a. They believed that selecting which treatment alone is insufficient without their blessings especially for parents and husbands of married women. For many informants, Islam has taught them to believe that every event including illness comes from Allah. In order to seek pleasure and barakah from Allah, one has to follow His teachings. One of the teachings include obeying or seeking blessings from parents for unmarried women and husbands for married women. They believed following the advice and decisions made by parents or husbands could eventually assist breast cancer patients to search for a cure. Furthermore, it is one of the important values or tenets taught in Islam.

\section{Conclusion}

Malay informants had associated their breast cancer illness with divine reason. Majority of the patients interviewed had initially encountered the possibility of dying soon. For many of them, the word 'cancer' is equivalent to death. This includes fear of death or unknown reasons for the symptoms suffered. In relation to this, religion is seen as a comforting factor to rationalise the 'inexplicable' situation in life. In most cases, breast cancer patients perceived their breast cancer illness episode as a life awakening experience. The illness had brought them to be closer in terms of relationship with Allah, family members and friends. They become redha (acceptance) with the gada' and qadar of Allah as they turned inward and found meaning in their predicament. The redha concept is part of the 
spiritual healing approach adopted by them. The spiritual healing approach includes reciting verses from the Qur'an, making du'a and performing daily prayers. They strongly believed that the key factor for a healthy life is by improving their relationship with Allah for $\mathrm{He}$ is the curer of all illnesses. Thus, the findings of this study had made it visible that the Islamic religious belief had superseded the Malay cultural belief in the lives of the Malay informants after breast cancer diagnosis. At this juncture, it was observed that informants were becoming more religious and pious after breast cancer diagnosis.

In addition, the findings of this study have also shown evidently the importance of social support provided by family and non-family members in complying with the medication prescribed. These include words of encouragements from their loved ones, seeking for alternative treatments, words of wisdoms, accepting their ill-health as qada' and qadar and submitting oneself to Allah as His test and rewarding rather than divine punishment. The role of immediate family members such as parents and husband is imperative in alleviating pain suffered by the breast cancer patients. Most significantly, their behaviour are regulated by religious values i.e. jangan derhaka (disobedient) and at the same time, securing blessings for good health, barakah (blessings) and finally be cured from cancer.

This in many ways leads to our understanding of medical pluralistic attitude observed among the breast cancer patients. The medical pluralistic attitude is further strengthened or substantiated by the fact that traditional medical system and modern medical system existed in parallel in society. In other words, informants or breast cancer patients had options to seek for a cure in treating their chronic pain or illnesses. This study had assisted our understanding the psychological dimension of patients of which the aim for such pluralistic attitude towards medication was aimed to seek for a cure.

\section{ACKNOWLEDGEMENT}

This paper is supported by P-RIGS18-011-0011 grant from International Islamic University Malaysia (IIUM).

\section{References Références Referencias}

1. Barkwell, D. (2005). Cancer pain: Voices of the Ojibway people. Journal of Pain and Symptom Management, 30 (5), 454-464.

2. Devi, K. M. and Fong, K. C. K. (2019). Spiritual experiences of women with breast cancer in Singapore: A qualitative study. Asia Pacific Journal of Oncology Nursing 6 (2), 145-150.

3. Farizah A., Mazanah. M and Amini, A. A.. (2011). Religion and spirituality in coping with advanced breast cancer: Perspectives from Malaysian Muslim women. Journal of Religion and Health, 50, 36-45.

4. Horbst, V. et al. (2017). Revisiting medical pluralism. L'Uomo, 1, 7-26.

5. Kleinman, A. (2019). The soul in medicine. The Lancet, 394 (10199), 630-631.

6. Kleinman, A. (1997). Everything that really matters: Social suffering, subjectivity, and the remaking of human experience in a disordering world. The Harvard Theological Review, 90 (3), 315-335.

7. Leao, D. et al. (2019). The importance of spirituality for women facing breast cancer diagnosis: A qualitative study. International Journal of Environmental Research and Public Health, 18(12), 1-11.

8. Mahmud, H. et al. (2019). Cancer: A medical anthropological study on peoples' understanding and therapy management process. The Journal for Social Advancement, 3, 373-381.

9. Miller, M. et al. (2021). Pain and spirituality among women with advanced breast cancer: Insights from a phenomenological study. Cancer Care Research Online: 1-7.

10. Movafagh, A. et al. (2017). Spiritual therapy in coping with cancer as a complementary medical preventive practice. Journal of Cancer Prevention, 22 (2), 82-88.

11. Norhasmilia, S., Mazanah, M., and Krauss, S. E. (2015). Why cancer patients seek Islamic healing. Journal of Religion and Health, 55 (5), 1507-1518.

12. Singh, R. (2017). The pain: How does anthropology look at it? Suffering of body and mind. Ethnologia Actualis, 17(2), 123-139. 